\title{
URGE URINARY INCONTINENCE AND PELVIC ORGAN PROLAPSE TREATMENT BY CERVICOSACROPEXY (CESA): FIRST STEPS IN LITHUANIA
}

\author{
Mindaugas Danilevičius ${ }^{1}$, Ieva Vasilavičiūtè2 ${ }^{2}$ Raimundas Venckus ${ }^{1}$, Vinsas Janušonis ${ }^{3}$ \\ ${ }^{1}$ Klaipéda University Hospital, Clinic of Abdominal and Endocrine Surgery, \\ Department of Urology, ${ }^{2}$ Lithuanian University of Health Sciences, Medical Academy, \\ ${ }^{3}$ Klaipèda University, Klaipeda University Hospital, Lithuania
}

Key words: cervicosacropexy (CESA), vaginosacropexy (VASA), urinary incontinence, overactive bladder syndrome, mixed urinary incontinence, polyvinylidene fluoride tape, uterosacral ligaments.

\begin{abstract}
Summary
Background. The purpose of our study is to evaluate and present the results of the first cervicosacropexy (CESA) in Lithuania, which was performed in Klaipeda university hospital.

Materials and methods. For the 62 years old female patient suffering from overactive bladder syndrome, confirmed by urodynamic test, and $\mathrm{II}^{\circ}$ pelvic organ prolapse (by pelvic organ prolapse quantification classification) cervicosacropexy using polyvinylidene fluoride (PVDF) tape was performed in Klaipeda University Hospital in 2016. Urinary incontinence was evaluated by voiding diary, International Consultation on Incontinence Modular Questionnaire - Short Form (ICIQ-SF) and Overactive Bladder Symptom Score (OABSS), that were filled by the patient before the surgery and 2, 4, 8 weeks after it. Urinary urgency, episodes of urinary incontinence, the need of sanitary pads and urinary frequency were compared before and after the surgery. To assess urinary incontinence impact on daily life, the General King's Health Questionnaire (GKHQ) was used before and after the procedure.

Results. After the surgery decrease of episodes of urinary incontinence, urinary frequency during day and night, urinary urgency and the need of sanitary pads were observed. Moreover, the patient could hold the urine longer after feeling the need to urinate. Scores of ICIQ-SF and OABSS decreased. GKHQ revealed considerable improvement in quality of life after CESA. Social life, mental and phy-
\end{abstract}

sical health of the patient were improved, and sexual life was unchanged.

Conclusions. After CESA surgery using PVFD tape, functional indicators and quality of life were improved. First results of this surgery are very good and promising.

\section{Introduction}

Urge urinary incontinence (UUI) is a bothersome urogenital disorder that affects approximately one third of postmenopausal women. Urgency, frequency and incontinence - this triad has detrimental effects on the patient's quality of life and proves to be a source of anxiety [1]. According to Herzog, Fultz and Thom, about $40 \%$ of all women will develop urinary incontinence during their life, usually starting around the age of $50[3,4]$. This is a debilitating disorder, which massively restricts the social and private life of the patient [5]. Known pharmacological treatment attempts to reduce the urinary incontinence symptoms; however, there is no cure addressing the basic cause of the disease [6]. Moreover, pharmacological treatment is slightly more effective than placebo [7]. Treatment of UUI is now focused on antimuscarinic drug therapy, botulinum intravesical injection, sacral neuromodulation, and behavioral interventions [7]. Despite many known treatment methods of UUI, surgery is not widely practiced.

Little is known about causes of UUI. Recent physiological and clinical researches are focused on descriptions and development of etiological theories. The most promising theories indicate abnormalities in control of bladder function resulting from aberrations of neurological signals from the bladder (sensation) as well as signals from continence controlling central and peripheral nervous system [7].

In 1991 de Lancey emphasized the importance of the support of the genital tract for continence function [8]. $\mathrm{He}$ considered that the attachments of the ligaments at the 
cervix are so important that he proposed to perform supracervical hysterectomy instead of total hysterectomy whenever possible. Observations of the patients suffering from descensus uteri suggested the critical role of supportive structures for incontinence and especially for UUI. Up to $50 \%$ of these patients had UUI $[9,10]$. Descensus uteri is not a disease of the uterus, so it is not surprising that neither vaginal nor abdominal hysterectomy can cure UUI in these patients [11]. In 1996 Petros 'Integral Theory' pointed out the importance of the posterior compartment for establishing continence function [12]. He assumed that the uterosacral ligaments (USL) are essential for causing UUI. According to the 'bridge allegory' they are the 'tows at the pylons which keep the vagina in the correct position' (Fig. 1). Association between descensus uteri and UUI could be caused by a defective functioning of the USL.

In 2000, Barber et al. reported a new surgical procedure for the treatment of pelvic organ prolapse [13]. Basically, they sutured the apex of the vagina to the left and right ute-

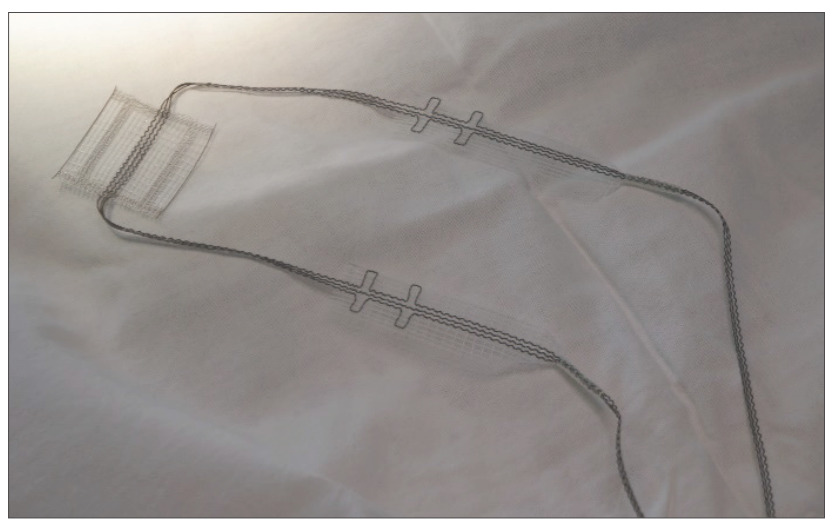

Fig. 1. Polyvinylidene fluoride tape used in cervicosacropexy.

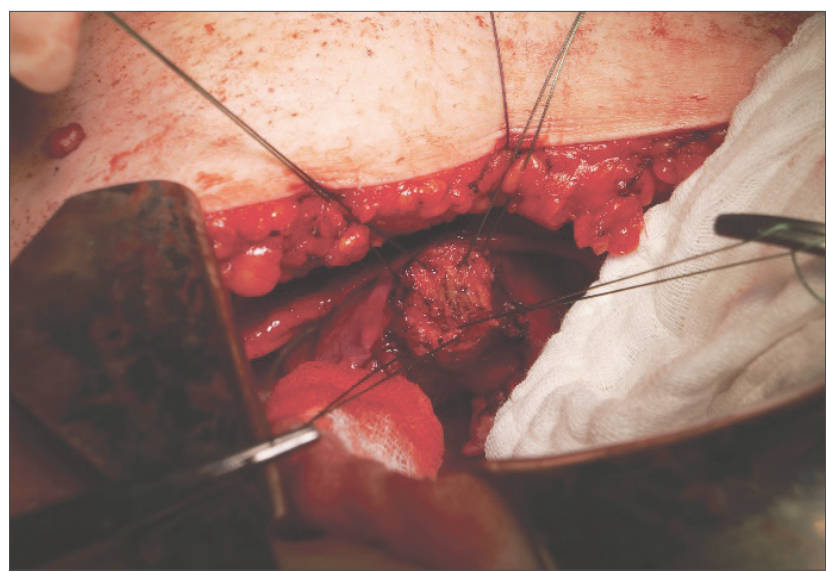

Fig. 2. Placement of four non-absorbable 2-0 sutures in the cervical stump after the subtotal hysterectomy. rosacral ligament (USL). Besides the "excellent anatomical correction of the prolapse", they observed a "significant improvement of voiding function" [13]. In 2003, Amundsen combined this bilateral uterosacral ligaments fixation with a pubovaginal sling in patients who additionally suffered from stress urinary incontinence (SUI) [14]. In all of their 33 patients, SUI was successfully treated after this combined procedure. However, the most remarkable observation in this study was that 14 out of 17 patients $(82 \%)$ who were suffering from UUI were cured after these operations.

In 2004, W. Jager started to repair the USL in these patients instead of removing the uterus. Since the USL in postmenopausal women were more or less a peritoneal fold with only microscopically detectable musculature, a classical repair was not possible. He replaced it with alloplastic tapes and concluded that most patients $(77 \%)$ with urge and mixed urinary incontinence can be cured by surgery [15]. In 2011, development of tapes began with the FEG

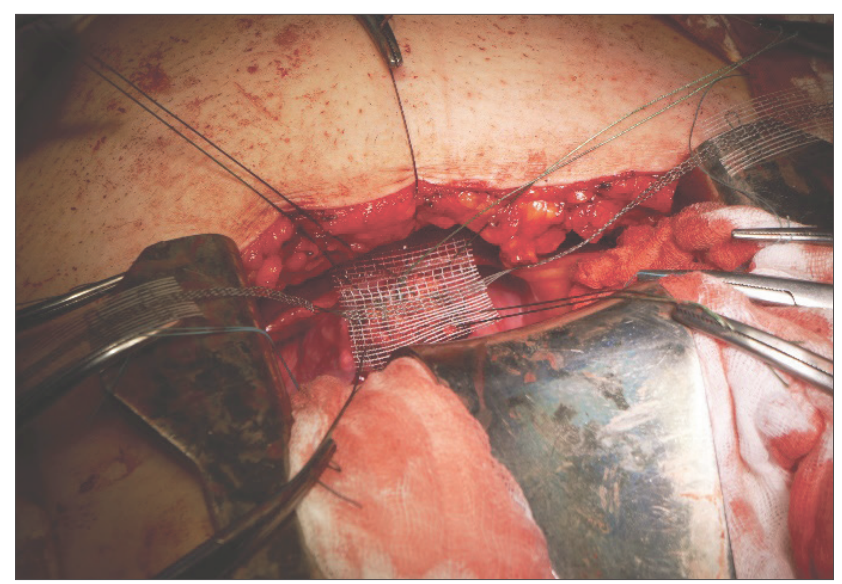

Fig. 3. Fixation of PVDF tape to the middle of the cervical stump.

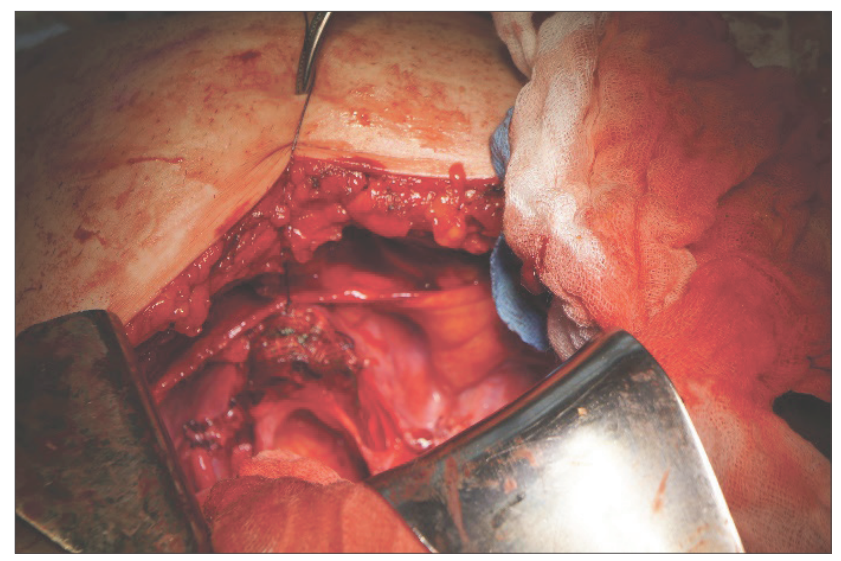

Fig. 4. Uterosacral ligaments channel after PVDF tape insertion. Black arrows: uterosacral ligaments. 


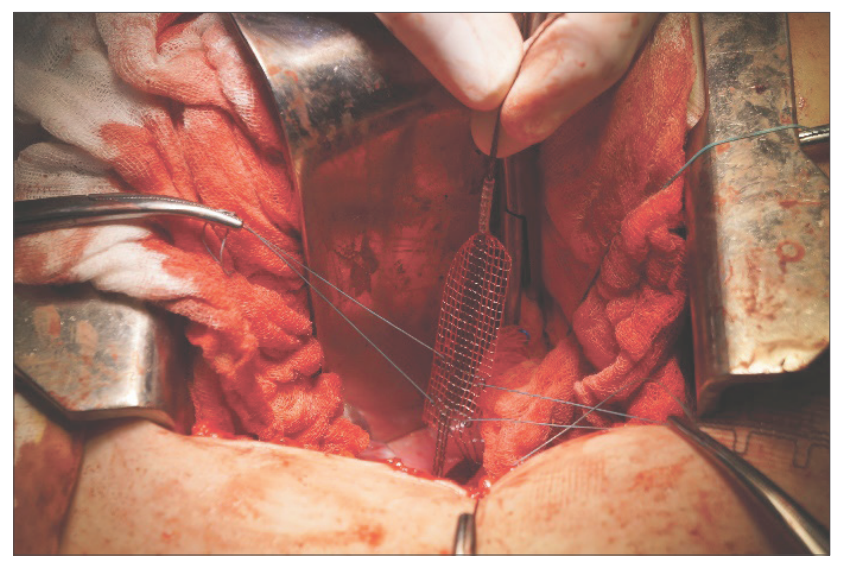

Fig. 5. Fixation of PVDF tape to sacrum.

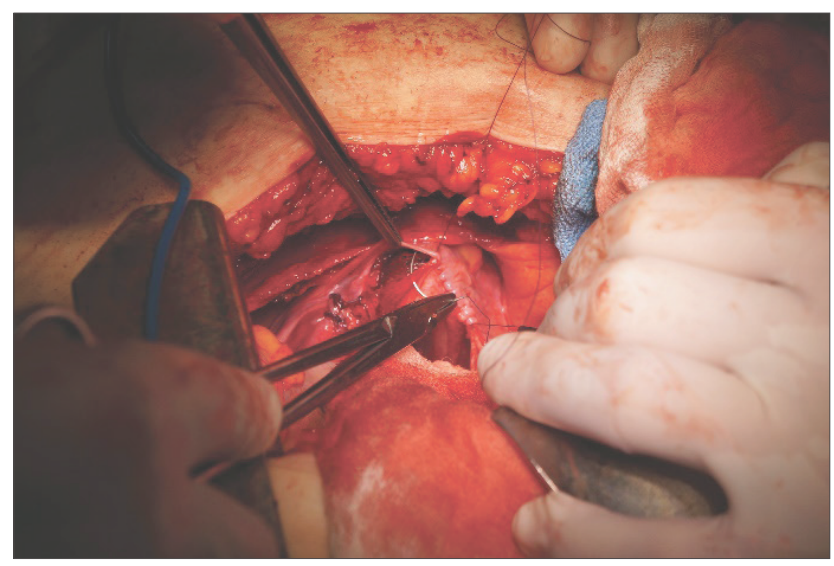

Fig. 6. Complete peritonealisation.

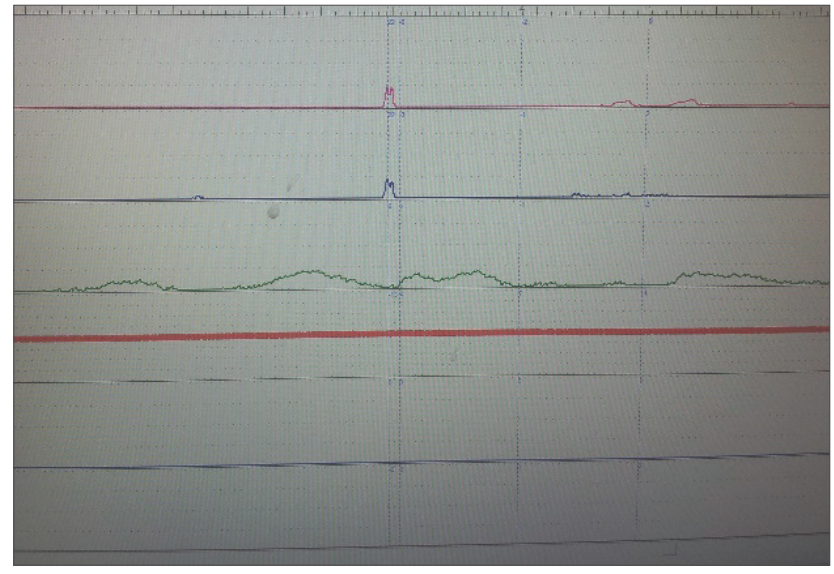

Fig. 7. Urodynamic test before CESA reveals 5 episodes of detrusor overactivity.

Textiltechnik, which already had developed and distributed the high performance plastic - polyvinylidene fluoride

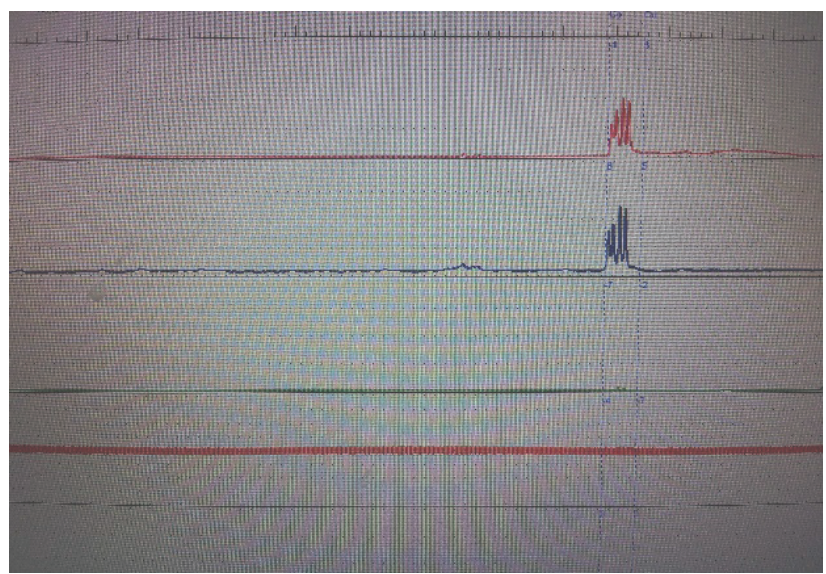

Fig. 8. Normal findings on urodynamic test 8 weeks after CESA.

(PVDF). Within the scope of this development four structures were specially adapted for the application of each of the CESA and cervicorectosacropexy (CERESA) as well as VASA and vaginorectosacropexy (VARESA) techniques.

The purpose of our study is to evaluate and present the results of the first CESA in Lithuania, which was performed in Klaipeda University Hospital.

\section{Materials and methods}

In this case report we are discussing a successful surgical treatment of urinary incontinence in 62 age female patient. Before the surgery a stress test and detailed urodynamic examinations were done. $\mathrm{II}^{\circ}$ pelvic organ prolapse (POP) was clinically diagnosed based on pelvic organ prolapse quantification (POP-Q) classification. The patient was hospitalized in Klaipeda University Hospital Department of Urology in August 2016. The first cervicosacropexy (CESA) operation using polyvinylidene fluoride (PVDF) tape (Fig.1) was performed in Lithuania.

Firstly, subtotal hysterectomy was performed through the $10 \mathrm{~cm}$ abdominal incision. Secondly, the distal edges of PVDF tapes were attached with four non-absorbable 2-0 sutures to the middle of the cervical stump (Fig. 2, 3).

Thirdly, the proximal edges of the PVDF tape using insertion aid were pulled extraperitoneally through the uterosacral ligaments channel (Fig. 4) and sutured to the presacral fascia in front of the S2 sacral vertebra (Fig. 5).

Lastly, peritonealisation was made with 'Vicryl' (Johnson\&Johnson, USA) 3-0 sutures in order to avoid contact between intestines and PVDF tapes (Fig. 6).

The procedure was finalized with the closure of the abdominal cavity and $16 \mathrm{Ch}$ size Foley catheter insertion to the bladder. It was taken out during the first day after the surgery. Sutures were removed from the wound 14 days after the surgery. 
Before the surgery and during the follow-up of $2^{\text {nd }}, 4^{\text {th }}$, and $8^{\text {th }}$ week POP were evaluated clinically, urinary incontinence and frequency of urination were assessed using the patient voiding diary, International Consultation on Incontinence Modular Questionnaire-Short Form (ICIQSF) and Overactive Bladder Symptom Score (OABSS). In addition to this, urinary urgency, episodes of incontinence, the need of pads and urinary frequency were compared before and after the procedure. In order to assess urinary incontinence impact on daily life, the General King's Health Questionnaire (GKHQ) was used before and after the CESA procedure.

\section{Results}

For the first time in Lithuania, CESA using PVDF tape was performed for the patient, who was diagnosed with UUI and POP, on August 5, 2016 in Klaipeda University Hospital Department of Urology. Duration of the surgery was 2 hours and 10 minutes, with no intraoperative and postoperative complications observed.

CESA was performed for the 62-year-old patient, who was diagnosed with POP 16 years ago and UUI 9 years ago. She had 4 vaginal deliveries, each newborn birth weight was over $3500 \mathrm{~g}$. Menopause occurred at the age of 50 . The patient underwent anterior colporrhaphy as a treatment for POP in 2002. After one year relapse of POP was diagnosed. For a half year the patient took M-cholinoblockers irregularly, with no significant effect. The symptoms progressed, but she sought for professional help only in 2006. Before the CESA surgery urine culture (negative), stress test (patient could hold urine when lying down and standing up)

Table 1. Frequency of the symptoms before and after CESA.

\begin{tabular}{|l|c|c|c|c|}
\hline Symptom & $\begin{array}{c}\text { Before } \\
\text { CESA }\end{array}$ & $\begin{array}{c}\text { 2 weeks af- } \\
\text { ter CESA }\end{array}$ & $\begin{array}{c}\text { 4 weeks af- } \\
\text { ter CESA }\end{array}$ & $\begin{array}{c}\text { 8 weeks af- } \\
\text { ter CESA }\end{array}$ \\
\hline Urinary urgency & + & - & - & - \\
\hline $\begin{array}{l}\text { Urinary inconti- } \\
\text { nence }\end{array}$ & 1 & 0 & 0 & 0 \\
\hline Nocturia & $3-4$ & 1 & 1 & 1 \\
\hline $\begin{array}{l}\text { No. of sanitary } \\
\text { pads }\end{array}$ & 1 & 0 & 0 & 0 \\
\hline $\begin{array}{l}\text { Urinary frequency } \\
\text { during the day }\end{array}$ & $12-15$ & 10 & 8 & 8 \\
\hline $\begin{array}{l}\text { The feeling of } \\
\text { incomplete blad- } \\
\text { der emptying }\end{array}$ & - & - & - & - \\
\hline $\begin{array}{l}\text { Permanent urine } \\
\text { flow }\end{array}$ & - & + & + & + \\
\hline
\end{tabular}

Table 2. The ability to hold urine.

\begin{tabular}{|l|c|c|c|c|}
\hline $\begin{array}{l}\text { The ability to } \\
\text { hold urine }\end{array}$ & $\begin{array}{c}\text { Before } \\
\text { CESA }\end{array}$ & $\begin{array}{c}\text { 2 weeks af- } \\
\text { ter CESA }\end{array}$ & $\begin{array}{c}\text { 4 weeks af- } \\
\text { ter CESA }\end{array}$ & $\begin{array}{c}8 \text { weeks af- } \\
\text { ter CESA }\end{array}$ \\
\hline $3-10 \mathrm{~min}$ & & + & + & + \\
\hline$<3 \mathrm{~min}$ & + & & & \\
\hline
\end{tabular}

and Bonney test (negative) were performed. Also, before the surgery urodynamic test showed five episodes of detrusor overactivity (Fig. 7). Fortunately, 8 weeks after the surgery episodes of detrusor overactivity were not observed (Fig. 8).

However, there was no clinically significant difference between preoperative and postoperative bladder capacity (278 $\mathrm{ml}$ and $299 \mathrm{ml}$ respectively). Moreover, no major changes were observed in intraabdominal and intravesical pressures before and after CESA $\left(\mathrm{P}_{\text {ves }}\right.$ and $\mathrm{P}_{\text {abd }}$ from 7 to 14 $\mathrm{mmH}_{2} \mathrm{O}$ ). Bonney test was negative before and after the surgery and because of that stress or mixed incontinence were not determined for this patient. According to POP-Q classification $\mathrm{II}^{\circ} \mathrm{POP}$ was diagnosed before the operation, but in 2, 4 and 8 weeks after CESA, POP was no longer observed.

As table 1 shows, after the surgery there was determined a significant decrease of episodes of urinary incontinence, urinary frequency during the day and night. Likewise, urinary urgency and the need of sanitary pads were also reduced. Urine flow was no longer interrupted after the surgery, the patient did not feel incomplete bladder emptying and could hold the urine longer after feeling the need to urinate (Table 2).

Clinically significant difference was noticed between ICIQ-SF scores: 11 points before the surgery vs 3 points at 2 weeks, 2 points at 4 and 8 weeks after the surgery.

When comparing OABSS it is notable, that scores from

Table 3. Overactive Bladder Symptom Score.

\begin{tabular}{|c|c|c|}
\hline Question & Frequency & Score \\
\hline \multirow{3}{*}{$\begin{array}{l}\text { How many times do you typi- } \\
\text { cally urinate from waking in } \\
\text { the morning until sleeping at } \\
\text { night? }\end{array}$} & $\leq 7$ & 0 \\
\hline & $8-14$ & 1 \\
\hline & $\geq 15$ & 2 \\
\hline \multirow{4}{*}{$\begin{array}{l}\text { How many times do you typi- } \\
\text { cally wake up to urinate from } \\
\text { sleeping at night until waking } \\
\text { in the morning? }\end{array}$} & 0 & 0 \\
\hline & 1 & 1 \\
\hline & 2 & 2 \\
\hline & $\geq 3$ & 3 \\
\hline \multirow{6}{*}{$\begin{array}{l}\text { How often do you have a sud- } \\
\text { den desire to urinate, which is } \\
\text { difficult to defer? }\end{array}$} & Not at all & 0 \\
\hline & Less than once a week & 1 \\
\hline & Once a week or more & 2 \\
\hline & About once a day & 3 \\
\hline & 2-4 times a day & 4 \\
\hline & 5 times a day or more & 5 \\
\hline \multirow{6}{*}{$\begin{array}{l}\text { How often do you leak urine } \\
\text { because you cannot defer the } \\
\text { sudden desire to urinate? }\end{array}$} & Not at all & 0 \\
\hline & Less than once a week & 1 \\
\hline & Once a week or more & 2 \\
\hline & About once a day & 3 \\
\hline & 2-4 times a day & 4 \\
\hline & 5 times a day or more & 5 \\
\hline
\end{tabular}


10 points preoperatively decreased gradually to $4-3$ points during the follow-up (Table 3).

In addition, General King's Health Questionnaire (GKHQ) revealed considerable difference between quality of life before and after CESA. Social life, mental and physical health of the patient were improved. However, the patient did not observe significant difference in sexual life.

\section{Discussion and conclusions}

Prof. Dr. W. Jager used CESA/VASA technique as POP and urge or mixed urinary incontinence treatment for the first time in 2004 in Germany. Since classical repair of uterosacral ligaments was not possible for that patient because of their atrophy, he used alloplastic tapes to replace it [15]. However, the dilemma was, which material is the best for this type of operation. The implants could be made of polypropylene (PP), polyethylene terephthalate (PET), expanded polytetrafluoroethylene (ePTFE), polyvinylidene fluoride (PVDF), and absorbable materials, such as polylactide (PLA), polyglycolic acid (PGA), polycaprolactone (PCL) and polydioxanone (PDO) [16]. In studies PVDF showed highly effective porosity [17], stability [18], less foreign body reaction [19] and superior ageing resistance [20]. Prof. Dr. W. Jager used polyvinylidene fluoride tape and the first results demonstrated, that urge and mixed urinary incontinence could be treated not only prescribing medication, but also by the surgery. CESA/VASA surgery had been performed for 135 women with urge or mixed urinary incontinence, of which 77\% (102) patients were cured and $18 \%$ (24) reported a subjective improvement after surgery. 19 patients developed a recurrence of their primary symptoms between 5 and 33 months after the surgery [15].

According to clinical studies, it is proven that the CESA/ VASA method with additional transobturator tape (TOT) procedure can be used as a treatment for moderate and severe forms of urinary incontinence. In our case, there was no need to perform a TOT procedure, because the patient had not been diagnosed with stress urinary incontinence.

Previous researches showed that over $50 \%$ of patients were cured by CESA/VASA operations where bilateral replacement of the USL was performed. When the remaining patients received an additional TOT procedure, the cure rate was increased up to more than $80 \%$ of the patients. It is notable, that the number of cured patients decreased with increasing their age. For younger than 60 years old patients the chance of cure is high - nearly $90 \%$, however the chance of cure decreases to $65 \%$ if the patient is older than 70 years old [21].

In $2012 \mathrm{~S}$. Ludwig et al. stated that the mean duration of CESA/VASA surgery was $85 \mathrm{~min}(45-240 \mathrm{~min})$, when in our first case it lasted $130 \mathrm{~min}$. Major complications, such as hemorrhages, bladder lesions, tape erosions, uri- nary tract infection or urinary retention were not observed during operation and after it [22].

W. Jager et al. hypothesized, that hormone replacement therapy (HRT) with estrogens could have a positive effect on postoperative results. It is noted, that most of the women, who were cured at the age of 70 had HRT until 65 years of age. Although in our case estrogen therapy was not used before the operation [21].

It is also known that imperative urination and nocturia disrupts sleep and have a negative impact on mental and physical health. According to recent researches $75 \%$ of patients who had gone through CESA/VASA surgery stated remarkable decrease of nocturia after the operation [22].

This clinical case shows satisfying postoperative results of CESA surgery using PVFD tape for UUI with the main positive outcomes being decrease of imperative urinating, nocturia, POP and subsequent improvement of quality of life.

\section{References}

1. Nygaard I. Idiopathic urge urinary incontinence. N Engl J Med 2010;363:1156-1162.

http://dx.doi.org/10.1056/NEJMcp1003849

2. Shamliyan TA, Kane RL, Wyman J, Wilt TJ. Systematic review: randomized, controlled trials of nonsurgical treatments for urinary incontinence in women. Ann Intern Med 2008; 148:459-473.

http://dx.doi.org/10.7326/0003-4819-148-6-200803180-00211

3. Thom D. Variation in estimates of urinary incontinence prevalence in the community: effects of differences in definition, population characteristics, and study type. J Am Geriatr Soc 1998;46:473-480.

http://dx.doi.org/10.1111/j.1532-5415.1998.tb02469.x

4. Herzog AR, Fultz NH. Prevalence and incidence of urinary incontinence in community-dwelling populations. J Am Geriatr Soc 1990;38:273-281.

http://dx.doi.org/10.1111/j.1532-5415.1990.tb03504.x

5. Van der Vaart CH, de Leeuw JR, Roovers JP, Heintz AP. The influence of urinary incontinenceon quality of life of community-dwelling 45-70 year old Dutch women. Ned Tijdschr Geneeskd 2000;144:894-897.

6. Hashim H, Abrams P. Pharmacological management of women with mixed urinary incontinence. Drugs 2006;66:591-606. http://dx.doi.org/10.2165/00003495-200666050-00002

7. Hartmann KE, McPheeters ML, Biller DH. Treatment of overactive bladder in women. Evidence Reports/Technology Assessments, No. 187. Rockville (MD): Agency for Healthcare Research and Quality (US); 2009 Aug. https://www.ncbi.nlm. nih.gov/pubmedhealth/PMH0005469/ (October 14, 2016)

8. De Lancey JO. Structural support of the urethra as it relates to stress urinary incontinence the hammock hypothesis. Am J Obstet Gynecol1994;170:1713-1723. http://dx.doi.org/10.1016/S0002-9378(12)91840-2 
9. Lakeman MME, van der Vaart CH, Roovers JP. Hysterectomy and lower urinary tract symptoms: a nonrandomized comparison of vaginal and abdominal hysterectomy. Gynecol Obstet Invest 2010;70:100-106. http://dx.doi.org/10.1159/000297507

10. Van Brummen HJ, van de Pol G, Aalders CIM, Heintz APM, van der Vaart CH. Sacro-spinous hysteropexy compared to vaginal hysterectomy as primary surgical treatment for a descensus uteri: effects on urinary symptoms. Int Urogynecol J 2003; $14: 350-355$.

http://dx.doi.org/10.1007/s00192-003-1084-x

11. Gustafsson C, Ekstrom A, Brismar S, Altman D. Urinary incontinence after hysterectomy - three-year observation study. Urology 2006;68:769-774.

http://dx.doi.org/10.1016/j.urology.2006.04.001

12. Petros PE, Ulmsten UI. An integral theory and its method for the diagnosis and management of female urinary incontinence. Scand J Urol Nephrol 1993;153:1-93.

13. Barber MD, Visco AG, Weidner AC, Amundsen CL, Bump RC. Bilateral uterosacral ligament vaginal voult suspension with side-specific endopelvic fascia defect repair for treatment of pelvic organ prolapse. American journal of obstetrics and gynecology 2000;183:1402-1411.

http://dx.doi.org/10.1067/mob.2000.111298

14. Amundsen CL, Flynn BJ, Webster GD. Anatomical correction of vaginal vault prolapse by uterosacral ligament fixation in women who also require a pubovaginal sling. J Urol 2003;169:1770-1774.

http://dx.doi.org/10.1097/01.ju.0000061472.94183.26

15. Jager W, Mirenska O, Brugge S. Surgical treatment of mixed and urge urinary incontinence in women. Gynecol Obstet Invest 2012;74(2):157-164.

http://dx.doi.org/10.1159/000339972

16. Zhu LM, Schuster P, Klinge U. Mesh implants: an overview of crucial mesh parameters. World J Gastrointest Surg 2015;7(10):226-36.

http://dx.doi.org/10.4240/wjgs.v7.i10.226

17. Muhl T. et al. New objective measurement to characterize the porosity of textile implants. Journal of biomedical materials research. Part B Applied biomaterials. 2007.

18. Klinge U, Binneboesel M, Kuschel S, Schuessler B. Demands and properties of alloplastic implants for the treatment of stress urinary incontinence. Expert review of medical devices 2007;4(3):349-359.

http://dx.doi.org/10.1586/17434440.4.3.349

19. Gerulis H, Grogas E, Borós M, Klosterhalfen B, Eimer C, Arndt A, Otto S, Barski D, Ysebaert D, Ramon A, Otto T. Inflammatory reaction as determinant of foreign body reaction is an early and susceptible event after mesh implantation. BioMed Research International 2014; https:/www.hindawi.com/journals/bmri/2014/510807/ (October 14, 2016)

20. Klink CD, Junge K, Binnebösel M, Alizai HP, Otto J, Neumann
UP, Klinge U. Comparison of long-term biocompatibility of PVDF and PP meshes. Journal of Investigative surgery 2011;24(6):292-9.

http://dx.doi.org/10.3109/08941939.2011.589883

21. Jager W, Ludwig S, Mallmann P. Does the patients age have an influence on the outcome of CESA (Cervico-Sacropexy) and VASA (Vagino-Sacropexy) for the treatment of urinary incontinence in women? Journal of Gerontology et Geriatric research 2016;5(1):277-291.

http://dx.doi.org/10.4172/2167-7182.1000277

22. Ludwig S, Stumm M, Neumann E, Becker I, Jäger W. Surgical treatment of urgency urinary incontinence, OAB (Wet), mixed urinary incontinence, and total incontinence by cervicosacropexy or vaginosacropexy. Gynecol Obstet 2016;6(9):404. http://dx.doi.org/10.4172/2161-0932.1000404

\section{HIPERAKTYVIOS ŠLAPIMO PŪSLES BEI PROLAP- SO GYDYMAS CERVIKOSAKROPEKSIJA (CESA): PIRMOJI PATIRTIS LIETUVOJE}

M. Danilevičius, I. Vasilavičiūtė, R. Venckus, V. Janušonis

Raktažodžiai: cervikosakropeksija (CESA), vaginosakropeksija (VASA), šlapimo nelaikymas, hiperaktyvi šlapimo pūslè, mišri inkontinencija, polivinilideno fluorido tinklelis, uterosakraliniai raiščiai.

Santrauka

Darbo tikslas. Ivvertinti ir pristatyti pirmosios Lietuvoje Klaipèdos universitetinèje ligoninèje dèl prolapso ir šlapimo nelaikymo atliktos cervikosakropeksijos (CESA) operacijos rezultatus.

Tyrimo medžiaga ir metodai. 62 metų amžiaus pacientei Klaipedos universitetineje ligonineje 2016 metais atlikta cervikosakropeksija panaudojant polivinilideno fluorido tinklelị. Ligonei diagnozuota bei urodinamiškai patvirtinta hiperaktyvi šlapimo pūslè, kliniškai nustatytas prolapsas (POP-Q II ${ }^{\circ}$ ). Šlapinimasis bei šlapimo nelaikymas prieš operaciją ir praèjus 2,4 ir 8 savaitèms po jos buvo vertinamas pagal pacientès užpildytą šlapinimosi dienyną, tarptautinès ekspertų grupès šlapimo nelaikymo modulinị klausimyną (ICIQ-SF) ir hiperaktyvios šlapimo pūslès klausimyną (OABSS). Lygintas staigus noras šlapintis, šlapinimosi dažnis, šlapimo nelaikymo epizodų skaičius, ịklotų poreikis prieš ir po operacijos. Bendrasis King'o sveikatos klausimynas (GKHQ) buvo panaudotas siekiant nustatyti šlapimo nelaikymo įtaką kasdieniniam gyvenimui prieš ir po operacijos.

Rezultatai. Po operacijos sumažèjo šlapimo nelaikymo dažnis, šlapinimosi dažnis dienos ir nakties metu, staigus noras šlapintis bei ịklotų poreikis. Užsinorèjus ligonė galèjo ilgiau sulaikyti šlapinimąsi. Vertinant ICIQ-SF ir OABSS, prieš ir po operacijos, nustatytas akivaizdus balų skirtumas mažejimo linkme. Gyvenimo kokybė pagal GKHQ prieš ir po operacijos taip pat ženkliai skyrèsi. Pagerèjo psichinè bei fizinè pacientès būsena, socialinis gyvenimas, tačiau pokyčių seksualiniame gyvenime pacientẻ nepastebèjusi.

Išvados. Po cervikosakropeksijos, panaudojant polivinilfluorido tinkleli, pacientei pagerèjo funkciniai šlapinimosi rodikliai bei gyvenimo kokybė. Pirmieji šios operacijos rezultatai, gydant šlapimo nelaikymą, yra labai geri ir daug žadantys.

Adresas susirašinèti: mindedan@gmail.com

Gauta 2016-10-13 